\title{
OPTICAL PROPERTIES OF DOUBLE-LAYER STRUCTURE PHTHALOCYANINE-TETRACYANOQUINODIMETHANE
}

\author{
Z. I. Kazantseva, E. G. Bortchagovsky, I. A. Koshets \\ Institute of Semiconductor Physics of the National Academy of Sciences of Ukraine, pr. Nauki 45, Kiev- \\ 22, 03022, Ukraine, telephone: +380-44-5259798 \\ e-mails: kazants@isp.kiev.ua ; bortch@yahoo.com; koshets@isp.kiev.ua;
}

\begin{abstract}
OPTICAL PROPERTIES OF DOUBLE-LAYER STRUCTURE PHTHALOCYANINE-TETRACYANOQUINODIMETHANE
\end{abstract}

\section{Z. I. Kazantseva, E. G. Bortchagovsky, I. A. Koshets}

Optical properties of double-layer structures consisting of $\mathrm{Cu}$-phthalocyanine vacuum evaporated film and Langmuir-Blodgett film of pentadecyl-7,7,8,8-tetracyano-1,4-quinodimethane (pentadecyl-TCNQ) were investigated by ellipsometry, photoconductivity and optical transmission. The obtained results indicate strong interaction between the materials; the resulting optical properties cannot be presented as the sum of those of the particular components. Two new effective absorption bands at 1.08 and $2.85 \mathrm{eV}$ were found for such structures. The band at $2.85 \mathrm{eV}$ coincides with a measured peak in photocurrent spectrum, which supports the idea on a charge transfer complex formation between $\mathrm{Cu}$-phthalocyanine to TCNQ.

Keywords: Organic semiconductors; Ellipsometry; Optical spectroscopy; Photoconductivity

\section{Анотація}

\section{ОПТИЧНІ ВЛАСТИВОСТІ БІШАРОВИХ СТРУКТУР ФТАЛОЦІАНІН- ТЕТРАЦІАНОХІНОДИМЕТАН}

\section{I. Казанцева, С. Г. Борщагівський, I. А. Кошець}

Методами еліпсометрії, фотопровідності та оптичного поглинання досліджені оптичні властивості бішарових структур, утворених тонкими плівками напорошеного в вакуумі фталоціаніну міді (CuPc) та плівками Ленгмюра-Блоджетт пентадецил 7,7,8,8-тетраціано-1,4хінодиметанау (пентадецил TCNQ). Отримані результати вказують на наявність взаємодії між речовинами; оптичні властивості системи не можуть бути представлені як проста суперпозиція складових компонент. У спектрі поглинання структури виявлено дві нові смуги 1.08 i $2.85 \mathrm{eV}$. Смуга $2.85 \mathrm{eV}$ співпадає з підвищенням сигналу в спектрі фотопровідності, що свідчить на користь гіпотези про утворення комплексу з переносом заряду між CuPc i TCNQ.

Ключові слова: органічні напівпровідники, еліпсометрія, оптична спектроскопія, фотопровідність. 


\title{
Аннотация \\ ОПТИЧЕСКИЕ СВОЙСТВА БИСЛОЙНЫХ СТРУКТУР ФТАЛОЦИАНИН- ТЕТРАЦИАНОХИНОДИМЕТАН
}

\begin{abstract}
З. И. Казанщева, Е. Г. Борщаговский, И. А. Кошеи
Методами эллипсометрии, фотопроводимости и оптического поглощения исследованы оптические свойства бислойных структур, состоящих из тонких пленок осажденного в вакууме фталоцианина меди (CuPc) и пленок Ленгмюра-Блоджетт пентадецил 7,7,8,8-тетрациано-1,4-хинодиметана (пентадецил TCNQ). Полученные результаты указывают на явное взаимодействие между этими веществами; оптические свойства системы в целом не могут быть представлены как простая суперпозиция составляющих компонент. В спектре поглощения структуры обнаружено две новые полосы 1.08 и $2.85 \mathrm{eV}$. Полоса $2.85 \mathrm{eV}$ совпадает с пиком в спектре фотопроводимости, что говорит в пользу гипотезы об образовании комплекса с переносом заряда между CuPc и TCNQ.
\end{abstract}

Ключевые слова: органические полупроводники, эллипсометрия, оптическая спектроскопия, фотопроводимость

\section{Introduction}

Charge transfer complexes (CTC) play an important role in many electrophysical and optical processes [1]. They exhibit interesting optical, electrical, and photoelectrical properties and can be used in many applications. Phthalocyanines (Pc) are a well-known class of organic semiconductors, which are recognized as a robust material for modern optoelectronics [2]. Having rather high-energy intermolecular interactions in the crystal, illuminated they can form polar charge-transfer states due to electron transfer between neighbor phthalocyanine molecules. This charge-transfer state can be dissociated by an external electric field and free charge carriers can be formed. Phthalocyanine molecule can form CTC with a strong electron acceptor even in the dark. 7,7,8,8Tetracyano-1,4-quinodimethane (TCNQ) having a high electron affinity is often used as the acceptor in such complexes [1]. In such CTC we expect the higher quantum efficiency of charge carrier generation under light exposure, which occurs not only in the spectral region of the phthalocyanine absorption but also in the spectral region of the optical absorption of $\mathrm{Pc}^{+}$ and TCNQ- ions. Our study was performed on planar structures consisting of layer of vacuum evaporated $\mathrm{Cu}$ phthalocyanine $(\mathrm{CuPc})$ and Langmuir-Blodgett film of pentadecyl-TCNQ (C15-TCNQ).

\section{Experimental details}

All optical measurements were carried out with variable angle spectroscopic ellipsometer from Woollam Co. (WVASE) having also the possibil- ity to operate in the spectrophotometer mode. Ellipsometry is well known to be a powerful tool for thin film investigations [3]. In the contrast to reflectometry where intensity reflection coefficients are measured for different polarizations, ellipsometry determines two so-called ellipsometric angles, which describe the change of the polarization state at the reflection. These angles are defined via complex amplitude reflection coefficients determined by the standard Fresnel formulae.

Investigated systems are double-layer structures from $\mathrm{Cu}$-phtalocyanine $(\mathrm{CuPc})$, which molecular structure is shown in the inset of Fig. 1 and pentadecyl-7,7,8,8-tetracyano-1,4-quinodimethane (C15-TCNQ) films. The structure of C15-TCNQ molecule is shown in the inset of Fig. 2.

CuPc layers with the thickness $60-100 \mathrm{~nm}$ were vacuum evaporated on silicon or fused silica substrates. After that several acceptor layers of C15TCNQ were deposited by the standard LangmuirBlodgett (LB) technique using a 'Lauda' trough. As obtained in the [4] a specific feature of the P-A isotherme (Fig. 3) for C15-TCNQ is the N-shape region in the range of surface area and surface pressure $20-40^{2} / \mathrm{mol}$ and $12-20 \mathrm{mN} / \mathrm{mol}$, respectively. It should be noted that the monolayer state characterized by the larger area $\left(40^{2} / \mathrm{mol}\right)$ is metastable and spontaneous transition to the small area $20^{2} / \mathrm{mol}$. Possible molecular orientation are shown in the inserts in Fig. 3. C15-TCNQ is an amphiphilic derivative of TCNQ, which is a rodlike molecule with quite high dipole moment. Due to this dipole moment, the monolayers exhibit a strong tendency to molecular 
reorganization both at the air-water interface and on a solid surface. This circumstance strongly affects the process of LB film formation, its transfer on the solid substrate, and finally the physical properties of the film. Due to the high dipole moment and strong electron affinity molecules of TCNQ remarkably perturb the electronic structure of the underlying material [4] that in turn influences the adsorbate dynamics and film structure. Freshly prepared $\mathrm{CuPc}$ film proved to be good substrate for the C15-TCNQ monolayer transferred by the LB technique. The quality of the deposited C15-TCNQ films was good; they were homogeneous up to 20 monolayers as it was visible even by naked eye. The transfer was of the $\mathrm{Y}$ type in contrast to the deposition on other substrates [5]. The resulting films were stable for months.

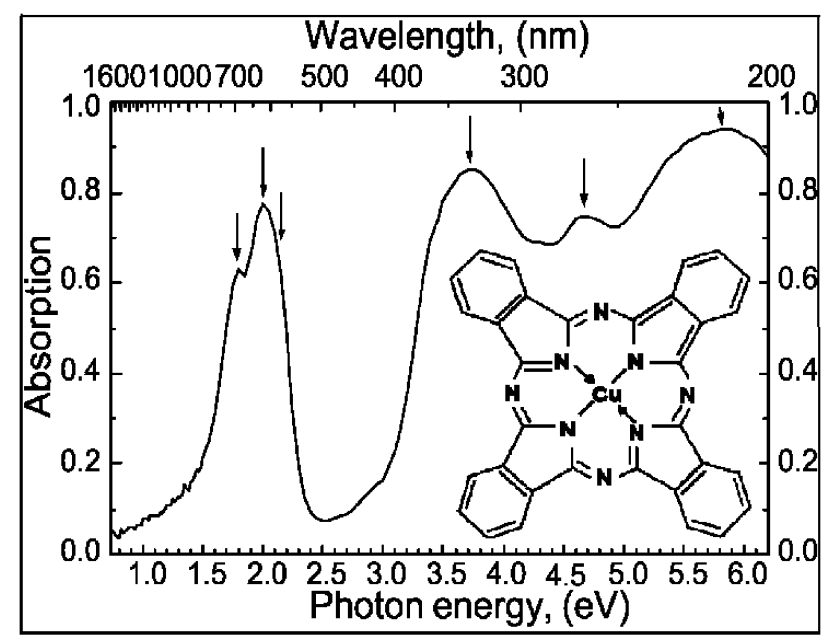

Fig.1. Absorption spectra measured for $\mathrm{CuPc}$ film on fused silica. Marked bands are: $1.79 ; 2.01 ; 2.13 ; 3.7$; $4.65 ; 5.8 \mathrm{eV}$. Chemical structure of CuPc molecule is included into plot.

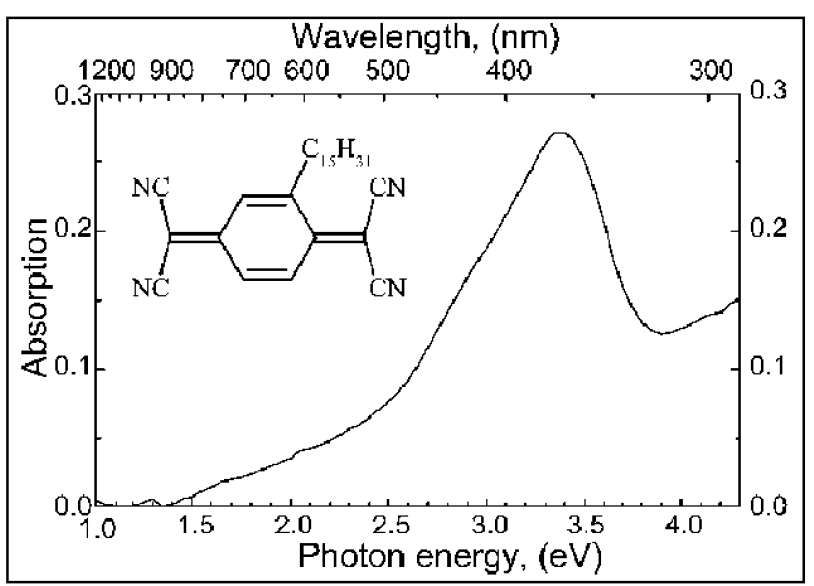

Fig.2. Absorption spectrum measured for 10 Z-type monolayers of C15-TCNQ on glass. Chemical structure of C15-TCNQ molecule is included into plot.

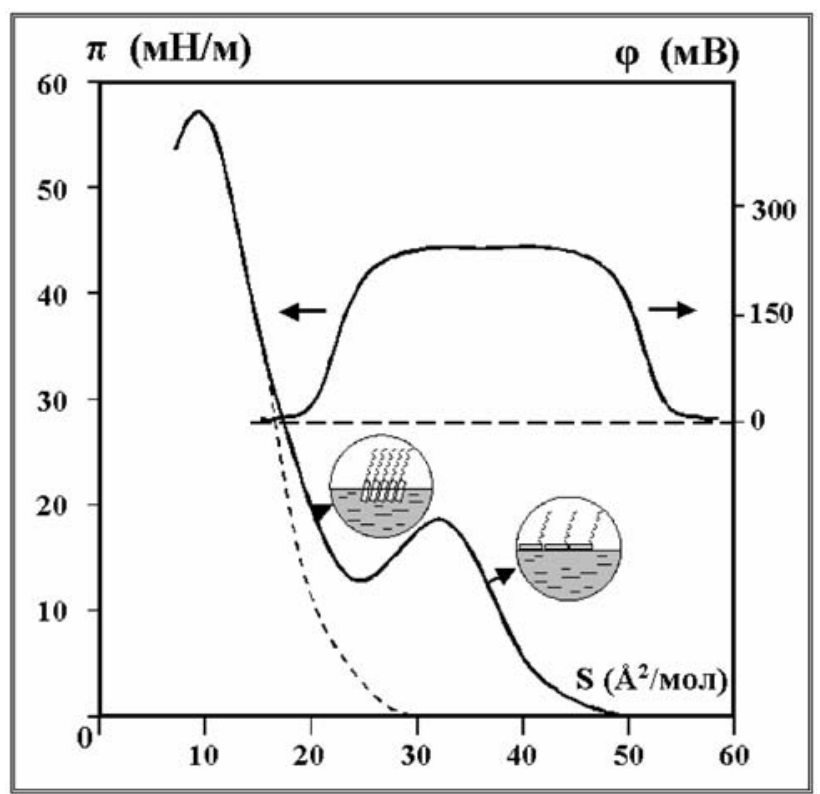

Fig.3. Surface pressure - area (P-A) and surface potential - area $(\triangle \mathrm{V}-\mathrm{A})$ diagrams for $\mathrm{C} 15-\mathrm{TCNQ}$ monolayer on bidistilled water subphase.

Investigations of photocurrent of C15-TCNQ structure have been carried out as well. Dark current and white light photocurrent, dependence of photocurrent vs. light flux and spectral photocurrent were measured. For that purpose installation shown on Fig. 4 has been assembled. Measured structure was mounted into special cell (8), which allowed of vacuumizing and shielding from electrostatic fields of the structure. As the light source (1) was used xenon lamp (XH 100), that provided with appropriable level of light flux. But, as xenon lamp is non-uniform light source, we had to use calibrated photodetector (6) to normalize light intensity overall spectrum under study. Monochromator (4) and neutral light filters (4) were used for spectral photocurrent and white light photocurrent experiments respectively. Photocurrent and signal of photodiode were measured with high precision electrometers Keithley K-614 (9).

\section{Results and discussion}

Measured absorption spectrum of a CuPc film of approximately $100 \mathrm{~nm}$ thick deposited on fused silica is presented in Fig. 1. It exhibits a well-known shape with $\mathrm{Q}$ band approximately $2 \mathrm{eV}, \mathrm{B}$ band at approximately $3.7 \mathrm{eV}$ and the next $\mathrm{N}$ and $\mathrm{L}$ bands located at higher energies. Positions of absorption maxima at 1.79, 2.01, 2.13, 3.7, 4.65 and $5.8 \mathrm{eV}$ are indicated. Such a spectrum is more correspondent to the stable $\beta$ phase of deposited CuPc [5]. 


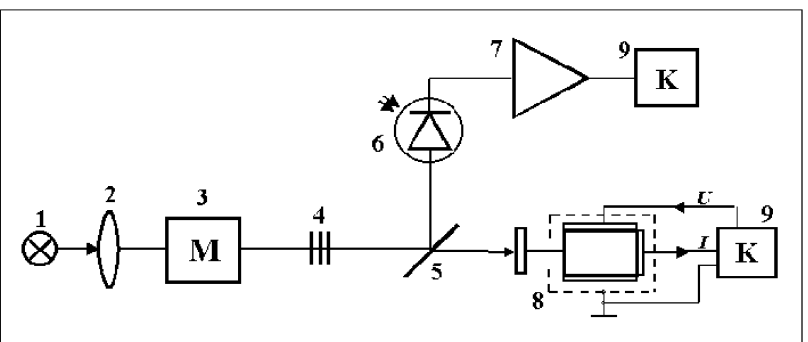

Fig.4. Schematic view of the installation for photocurrent measurements: 1 - xenon lamp; 2 - condenser;

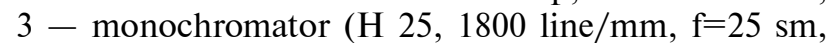
France); 4 - set of neutral light filters; 5 - semitransparent mirror; 6 - photodiode; 7 - photodiode amplifier; 8 - measurement cell; 9 - electrometer (Keithley, K-614).

The measured absorption spectrum of C15-TCNQ exhibiting a single absorption band with maximum at $3.4 \mathrm{eV}$ is presented in Fig. 2.

Unfortunately we were not able to deposit also $\mathrm{CuPc}$ by LB method to the thickness where photocurrent response risen over the noise to have completely ordered well defined system for investigations.

Fig. 5 presents the measured spectral photocurrent response of the double-layer structure $\mathrm{CuPc} / \mathrm{C} 15-\mathrm{TCNQ}$. It is seen that the spectral response of the photocurrent follows the absorption spectrum of vacuum deposited $\mathrm{CuPc}$.

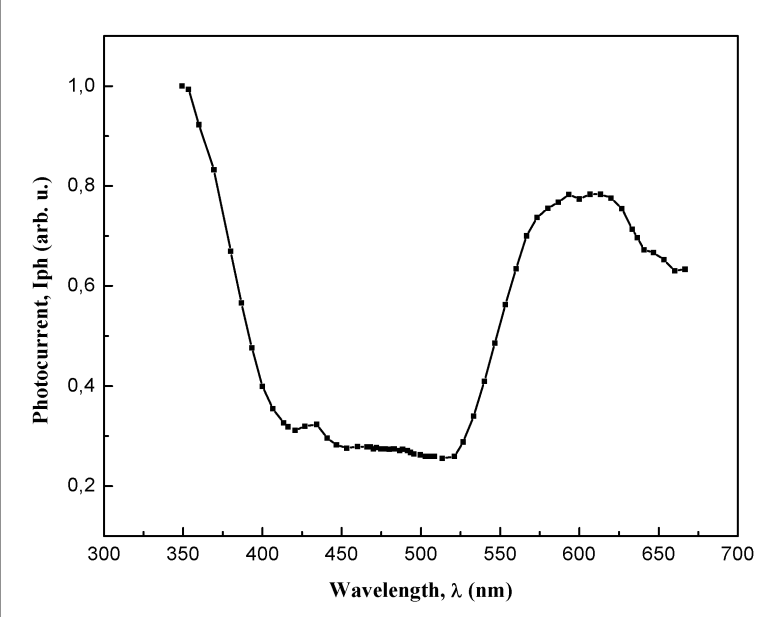

Fig. 5. Spectral photocurrent response of the doublelayer structure $\mathrm{CuPc} / \mathrm{C} 15-\mathrm{TCNQ}$.

The weak increase of the photocurrent in the region at approximately $2.85 \mathrm{eV}$ in comparison with the shown absorption curves, we prescribe to the absorption of anion radical TCNQ, which is formed due to an electron transfer in the dark. It must be stressed that the photocurrent under white light illumination was 28 times higher than the analogous response of the bare layer of vacuum deposited $\mathrm{CuPc}$. This fact demonstrates the efficiency of the interface $\mathrm{CuPc}-$ acceptor in pumping out of excitons created by light in $\mathrm{CuPc}$ and charge separation reflected in the rise of the photoconductivity.

The spectra of the effective absorption coefficient of the neat CuPc layer and the double-layer structure are presented in Fig. 6. It can be seen that spectral behaviour of the effective absorption coefficients for both structures is similar except for two additional absorption bands for double-layer structure with marked maxima at 2.85 and $1.08 \mathrm{eV}$.

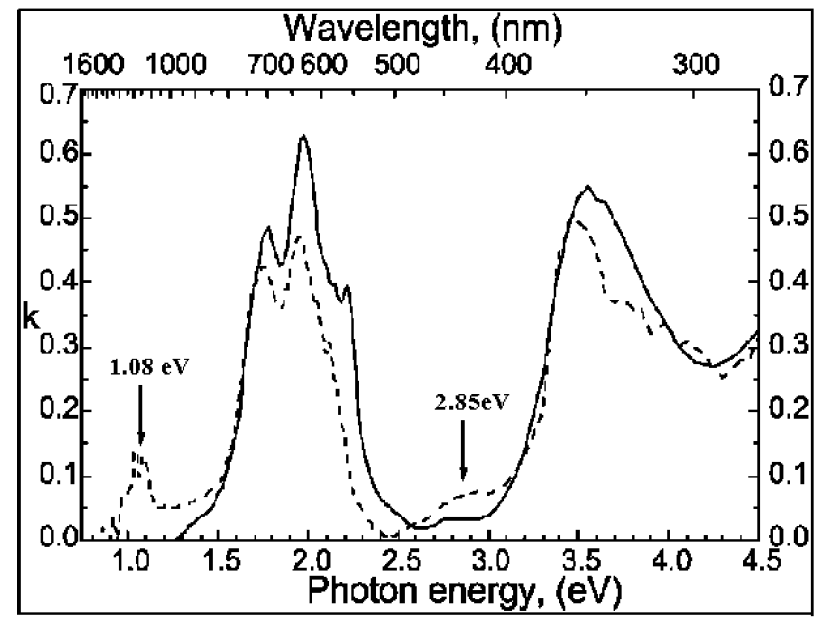

Fig. 6. Spectral dependences of absorption coefficients for pure CuPc film - solid line and for the CuPc film covered by TCNQ - dashed line. Effective coefficient exceeds the one for pure $\mathrm{CuPc}$ at marked points -1.08 and $2.85 \mathrm{eV}$.

The first band coincides spectrally with a weak response in the photocurrent spectrum and can be associated with the noticed formation of TCNQ ${ }^{-}$anion, as the second one corresponds to the chargetransfer absorption of the $\mathrm{CuPc}^{-} \mathrm{C} 15-\mathrm{TCNQ}$ structure. Unfortunately any quantitative photocurrent measurements in near infrared were impossible as the signal was far below the error level. Existence of the charge transfer supports the possibility to calculate the bigger thickness for the C15-TCNQ overlayer in the model of noninteracting layers. It is interesting to note that effective absorption in these bands is created by only a few deposited monolayers of C15-TCNQ and concentrated in the interface region definitely not propagating deep to $\mathrm{CuPc}$, but it is comparable with the calculated absorption of the whole $\mathrm{CuPc}$ film. 


\section{Conclusion}

The use of the simplest one 'effective' film approximation given valuable results for the doublelayer structure is presented. Attempts to separately use fixed optical parameters for the CuPc layer and C15-TCNQ overlayer to describe optical properties of the double-layer structures were not successful; optical properties of $\mathrm{CuPc}$ were definitely changed after the C15-TCNQ deposition. The presence of the acceptor layer (C15-TCNQ) deposited on the vacuum evaporated $\mathrm{CuPc}$ film makes possible the formation of the interface charge-transfer complex. The charge-transfer absorption was detected in the spectral region at approximately $1.1 \mathrm{eV}$. The new absorption band at $2.85 \mathrm{eV}$ was described by the absorption of TCNQ ${ }^{-}$anion. In the presence of the acceptor layer the photoelectric response was approximately 30 times higher than the analogous response of the bare $\mathrm{CuPc}$ layer-this fact can be important for solar cells fabrication. The increase of the photoconductivity in the spectral region of 2.85 $\mathrm{eV}$ suggests that TCNQ- anions can be effective in the photogeneration process.

\section{References}

1. J. Simon, J. - J. Andre, Molecular Semiconductors, Springer-Verlag, Berlin, 1985.

2. C.C. Leznoff, A.B.P. Lever (Eds.), Phthalocyanines Properties and Applications, VCH Publishers, 1989.

3. R.M.A. Azzam, N.M. Bashara, Ellipsometry and Polarized Light, North Holland Publishing, Amsterdam, 1977.

4. N.V. Lavrik, Z.I. Kazantseva, A.V. Nabok, B.A. Nesterenko, Phys. Low-Dimens. Struct. 1 (1995) 47.

5. M.A. Barrett, Z. Borkowska, M.W. Humphreys, R. Parsons, Thin Solid Films 28 (1975) 289. 